\title{
Tar vi vare på faglig og etisk kompetanse?
}

Det er stor forskjell på god sykepleie og sykepleie som er «god nok», skriver Terje Årsvoll Olsen i Rådet for sykepleieetikk.

\section{Terje Årsvoll Olsen}

Medlem av Rådet for sykepleieetikk og førstelektor

Høgskulen på Vestlandet

Sykepleien 2019107 (76754) (e-76754)

DOI: 10.4220/Sykepleiens.2019.76754

Iveren blant sykepleiere til å øke sin kompetanse har kanskje aldri vært høyere enn den er i dag. Og

tilbudene på universiteter og høyskoler med videreutdanninger, masterprogram og ph.d. har aldri vært mer innholdsrike og allsidige. Som sykepleier kan du ta både fagspesifikke og tverrprofesjonelle utdanninger og kurs, og med det heve både din faglige og etiske kompetanse. Men hvor står økt kunnskap, sterkere faglighet og etikk i relasjon til institusjonenes praksis og prioriteringer?

\section{Kompetanseheving koster}

Både ansatte og helsetjenesten investerer i kompetanseheving. Det brukes store summer på å legge til rette for at ansatte skal kunne $\varnothing$ ke sin kompetanse. Det gis fri med og uten lønn, det deles ut stipend, og mange bruker av egne midler for å sikre seg en videreutdanning eller en master. 
Da kravet om master kom for fullt, også kalt «mastersyken», resulterte det i et kor av klager, men dette har stilnet nå. Ikke alle deler av spesialisthelsetjenesten er heller så opptatt av at kandidatene i intensiv-, anestesi- eller operasjonssykepleie skal fullføre hele masteren. Vi ser likevel at det ansettes stadig flere med mastergrader eller ph.d. i helsetjenesten.

Det kan virke som om helsetjenestene er blitt mer villige til å betale for denne kompetansen. Men hvordan står det til med den kunnskapsbaserte praksisen? Vi arbeider nemlig innenfor en statlig regulert kunnskapsbasert praksis. Jeg er helt sikker på at det finnes mange steder der de ansatte både har tid og rom til å jobbe kunnskapsbasert. Mange steder holdes denne fanen høyt. Men dessverre ser vi i Rådet for sykepleieetikk at det en del steder ikke fungerer så godt.

\section{Pasientsikkerhet under press?}

Pasientsikkerhet er et satsingsområde både i helsetjenesten og i utdanningen. Likevel leser vi tidvis $\mathrm{i}$ avisene om un $\varnothing$ dvendige dødsfall på grunn av høyt arbeidspress og for lite bemanning.

En mann døde på akuttmottaket, fordi helsepersonell ikke hadde tid til å følge ham opp. Sykepleierne hadde over lang tid levert 100 avviksmeldinger knyttet til bemanningssituasjonen og pasientsikkerheten uten at det førte til noe (1). Det er dyktige medarbeidere som jobber i et akuttmottak, men det hjelper altså ikke når det ikke er nok av dem.

\section{«I enhetsledelsen har sykepleien, som er den egentlige grunnen til innleggelse, ofte tapt.»}


Forsker Terje Mesel (2) viser til tall fra Helse- og omsorgsdepartementet om at cirka 16 prosent av alle innleggelser i 2010 var forbundet med skade. 0,7 prosent av disse døde. Det vil si $4700 \mathrm{~d} \varnothing \mathrm{dsfall}$ per år. Vi fikk en nedgang etter innføringen av pasientsikkerhetsprogrammet i 2010-2012. Tallene for 2017 viser pasientskader i 13,7 prosent av pasientoppholdene. Antall skader som fører til forlenget innleggelse, har $\varnothing \mathrm{kt}$ i perioden 2012-2017. Antall skader som krevde livreddende behandling, eller som førte til d $\varnothing$ d, har sunket svakt i samme periode (3).

Årsaksforholdene er sammensatte: menneskelig svikt, systemsvikt, eller det kan være en organisering som ikke fungerer optimalt.

Vi vet at det er uunngåelig at feil skjer når mennesker er involvert. Samtidig vet vi at høyt press, høyt tempo, ventende pasienter og underbemanning svekker pasientsikkerheten. Slike forhold kan medføre at kompetent helsepersonell velger bort det å jobbe direkte pasientrelatert (2). Yrkesetiske retningslinjer (YER) punkt 1.3 sier at sykepleieren har et personlig ansvar for at egen praksis er faglig, etisk og juridisk forsvarlig. Om lag 18 ooo sykepleiere jobber ikke lenger som sykepleiere, og mange av disse oppgir at de ikke orket følelsen av å ikke strekke til, frykten for gjøre feil og opplevelsen av å være alene med ansvaret.

\section{Faglig forsvarlighet og omsorgsfull hjelp i skvis?}

Faggruppene melder til oss at omsorgsfullhet taper mot økonomien. Særlig barn er svært sårbare. Drivkraften for mange som vil bli sykepleiere, er $\emptyset$ nsket om å utgjøre en forskjell og om å hjelpe folk som har det vondt og vanskelig. Pasienter $\mathrm{d} \varnothing \mathrm{r}$ fortsatt ofte alene. Det er stor forskjell på god sykepleie og sykepleie som er «god nok». Flere faggrupper melder at rapporterte avvik ikke blir tatt på alvor før alvorlige hendelser inntrer. 


\section{Bortkastet å gå på kurs?}

Mange av oss har opplevd frustrasjon over å ha vært på kurs og fått ny innsikt og ny inspirasjon, bare for å komme tilbake på jobb og oppleve at det ikke er tid til å nyttiggjøre seg av det. Eller enda verre, ingen spør hva du har lært. Dette er både et lederansvar og et kollegaansvar. YER punkt 1.1 understreker at sykepleie skal bygge på forskning, erfaringsbasert kompetanse og brukerkunnskap. Hvis det ikke settes av tid til fagutvikling eller kompetanseheving, får man lite igjen for investeringen.

\section{Hvor blir det av personsentrert sykepleie?}

Personsentrert sykepleie er et mål, men ressursene strekker ikke til. Helseministeren og regjeringen snakker om pasientens helsetjenester, men fortsatt opplever sykepleiere at det er diagnosen som bestemmer og ikke en helhetlig pasientvurdering. Dette har med $\varnothing$ konomi og refusjonsordninger fra folketrygden å gjøre. Etikken kommer i andre rekke.

Studenter har rapportert at pasienter blir sendt mellom avdelinger med ut- og innprosedyrer for at DRG (diagnoserelaterte grupper) skal bli registrert. Det fører til for tidlige utskrivninger og retur i neste runde. Totalt er det 16 prosent reinnleggelser før det er gått 30 dager for pasienter over 67 år i Norge. (4). Sykepleiere er ofte ikke enige når legen sier at pasienten er ferdigbehandlet. Men det er ingen DRG for sykepleie og dermed ikke $\varnothing$ konomisk incentiv for sykepleie. 
Min påstand er at den eneste grunnen til at pasienter trenger å bli innlagt på sykehus, er at de trenger sykepleie - uten det kunne behandlingen foregått som dagkirurgi eller på poliklinikk. Har vi mot til å stå for dette? Har vi en tydelig stemme på pasientens vegne, eller er vi nikkedukker for systemet? Når sykepleieren i spesialisthelsetjenesten får beskjed fra legen om at pasienten er ferdigbehandlet, gjør hun da en sykepleiefaglig vurdering av om hun som sykepleier er ferdig med ham? I gamle dager var oversykepleierne en garantist for kvalitet. I enhetsledelsen har sykepleien, som er den egentlige grunnen til innleggelse, ofte tapt.

\section{Kvalitet på sykepleietjenesten}

Hvis kvaliteten i sykepleietjenesten skal styrkes og kompetanseutviklingen komme pasientene til gode, bør sykepleiere gis større tillit, og faget må avgjøre rett sykepleie- og omsorgsnivå, ikke økonomi eller DRG. Bemanningen må være slik at både etisk og faglig refleksjon får en plass. Underbemanning er selvforsterkende (5). Sykepleiere og annet helsepersonell må være profesjonelle pådrivere for faglig forsvarlighet og omsorgsfull hjelp. Det må det være full åpenhet om og refleksjon rundt kvalitet, også innenfor sykepleietjenesten. Pasientmedvirkningen må bli reell, men ikke en sovepute. Vi må spille på lag med pasienter og pårørende, og service må være fundamentet, ikke $1 \varnothing$ nnsomhet (6). Slik ivaretar vi faglig og etisk refleksjon og kompetanse.

\section{Referanser}

1. Otterlei SS. Sykepleierne varslet over hundre ganger om underbemanning før Daniel (43) døde. NRK.no. 19. desember 2018; kl. 05:48

2. Mesel T. Når noe går galt. Fortelling om skam, skyld og ansvar i helsetjenesten. Oslo: Cappelen Damm; 2014.

3. Helsedirektoratet. Pasientskader i Norge i 2017 Målt med Global Trigger Tool. Oslo: Helsedirektoratet; 2017. Rapport IS-2757. 
4. Helsedirektoratet. Reinnleggelse blant eldre 30

dager etter utskrivning per kommune. Oslo:

Helsedirektoratet; 07.03.2019. Tilgjengelig fra:

https://www.helsedirektoratet.no/statistikk/statistikk/kvalitetsindikatorer/kommunalehelse-og-omsorgstjenester/reinnleggelse-blant-eldre30-dager-etter-utskrivning-per-kommune (nedlastet 15.04.2019).

5. Gautun H, Øien H, Bratt C. Underbemanning er selvforsterkende - Konsekvenser av mangel på sykepleiere i hjemmesykepleien og sykehjem. Oslo: NOVA; 2016. Rapport 6/16.

6. Støstad JE. En tredje vei for velferden. På sporet av framtidas helse, omsorg og skole. Oslo: Gyldendal Arbeidsliv; 2015. 